\title{
ALMANYA (KRV) ALEVILIIK DÍN DERSİ ÖĞRETİM PROGRAMI İLE İSLAM DİN DERSİ ÖĞRETIMM PROGRAMININ KARŞILAŞTIRILMASI
}

\author{
Hasan SÖZENa
}

Öz

Bu çalışma, Almanya'nın Kuzey Ren-Vestfalya Eyaletinde uygulanmakta olan Alevilik Din Dersi Öğretim Programı (1-4. Sınıflar) ile İslam Din Dersi Öğretim Programının (1-4. Sınıflar) karşılaştırılması, aralarındaki benzerlik ve farklılıkların ortaya konulması amacıyla yapılmıștır. Çalıșmada nitel araștırma yöntemlerinden doküman incelemesi kullanılmış, söz konusu öğretim programları; temel alınan yaklaşım, öğretim programlarının yapısı ve içeriği, hedefleri ve genel kazanımları ile değerlendirme boyutları açısından incelenmiştir. Çalışma sonucunda Alevilik ile İslam din dersi öğretim programlarının, özellikle temel alınan yaklaşım, hedefler, yapısal özellikler ve ölçme-değerlendirme boyutlarıyla benzerlik gösterdiği belirlenmiştir. Her iki öğretim programında da Mezhep Merkezli Dinlerarası Açlımlı Din Öğretimi Yaklaşımı ile Korelasyon Didaktiği Yaklaşımının temel alındığı görülmüştür. Öğretim programlarının temel hedefleri incelendiğinde, bunların daha çok bireylerin dini kimlik gelişimine odaklandığı tespit edilmiştir. Her iki öğretim programının da benzer ölçme ve değerlendirme yaklaşımlarına sahip oldukları anlaşılmıştır. Öğretim programları arasında hem ünitelendirme hem de ünitelerin sınıf düzeylerine göre dağılımında ciddi farklılıklara rastlanmıștır. Alevilik Din Dersi Öğretim Programının İslam Din Dersi Öğretim Programına göre daha geniş ve detaylı bir konu içeriğine sahip olduğu tespit edilmiştir. Alevilik ile İslam din dersi öğretim programlarında her ne kadar Allah, Hz. Muhammed, Ehl-i Beyt, ibadet mekânları, dini gün ve geceler, diğer dinler, kutsal kitaplar vb. ortak konulara yer veriliyor olsa da genel olarak farklı konu içeriklerine, farklı anlayış ve yaklaşımlara sahip oldukları sonucuna ulaşılmıştır. Anahtar kelimeler: Din Eğitimi, Öğretim Programı, İslam, Alevilik, Almanya.

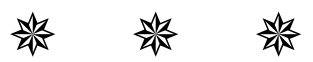

a Dr. Öğr. Üyesi, Bayburt Üniversitesi, hasan.sozen@mail.com 


\section{THE COMPARISON OF ALEVI RELIGION CURRICULUM AND ISLAM RELIGION CURRICULUM IN GERMANY (NRV)}

This study is carried out to compare and to reveal the similarities and differences between Religious Education Curriculum for Alevies (Grades 1-4) and the Islamic Religious Education Curriculum (Grades 1-4), which are being implemented in the North Rhine-Westphalia State of Germany. Accordingly, the basic approach, purpose, content, measurement and evaluation situations on which both programs are based are examined and evaluated based on the data obtained. The main problem of the study is "The comparison of Alevi and Islamic religion course teaching programs implemented in the German state of North Rhine-Westphalia".

In the study, qualitative research methods and document analysis are used, and the teaching programs in question are examined in terms of the approach over curriculum, the structure and content of the teaching programs, objectives and overall attainment, as well as evaluational dimensions of the course. The data obtained as a result of the analysis are grouped according to the criteria of similarity and difference, and the differences between the curriculums are interpreted based on the results obtained. During the analysis process, both teaching programs are examined closely and the necessary encodings are made. No categories have been previously defined for coding, except for problems and sub-problems.

[The Extended Abstract is at the end of the article.]

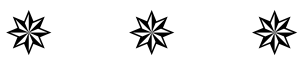

\section{Giriş}

İslam din derslerine yönelik talepler Almanya'da, özellikle de Kuzey Ren-Vestfalya Eyaletinde 1970 yllından itibaren dillendirilmeye başlanmıştır (Kiefer, 2011). 1973 yılına gelindiğinde ise dönemin Kuzey RenVestfalya Eyaleti başbakanı Heinz Kühn, İslam din derslerine yönelik çalışmaların ivedilikle başlatılması talimatını vermiştir (MSB, 2014). Bundan sonraki süreçte İslam din dersleri konusunda çeşitli öneriler geliştirilmiş, farklı din öğretimi yaklaşımları (Ana Dil Dersi Kapsamında Din Bilgisi Dersi/1978, Almanca Din Bilgisi-Kültürü Dersi/1999) tasarlanmış ve uygulamaya konmuştur (Topçuk, 2015; Zengin, 2008).

Kuzey Ren Westfalya Eyalet Meclisi, 21 Aralık 2011 tarihli

oturumunda "Okul Kanunu Değişiklik Yasası"nı
(Schulrechtsänderungsgesetz) görüşmüş ve oyçokluğuyla kabul etmiştir. 01.08.2012 tarihinde yürürlüğe giren bu yasayla birlikte İslam din derslerinin mezhep merkezli bir yaklaşımla ve Alman dilinde verilmesi 
kararlaştırmıştır. Böylece Almanca Mezhep Merkezli İslam Din Dersleri, 2012/13 Eğitim-Öğretim Yılından itibaren ilkokullarda, 2014/15 EğitimÖğretim Yılından itibaren de ortaokullarda yer almaya başlamıştır (Landtag NRW, 2011).

Alevilerin din derslerine yönelik talepleri ise 1980'lerin sonlarına doğru başlamış, 90'lı yıllara gelindiğinde hız kazanmıştır. Alevilik konularına ilk defa Hamburg'da, "Herkes İçin Din Dersi" din öğretimi modeli içinde yer verilmiştir. Bunu 2002 yılında Berlin'de uygulanmaya başlanan Alevi Din Dersleri izlemiştir. Almanya Alevi Birlikleri Federasyonu (AABF) 2001 yılında birçok eyalet hükümetine olduğu gibi Kuzey Ren-Vestfalya Eyaleti Hükümetine de dini cemaat olarak muhatap alınma, din dersi isteme ve verme talebinde bulunmuştur. Kuzey-Ren Westfalya Eyaleti Hükümeti yapılan başvuruyu incelemiş ve AABF'nin Federal Anayasanın 7/3 maddesine göre örgün eğitim kurumlarında din dersi isteme ve verme yetkisine sahip olduğuna ve dini cemaat olma bakımından gerekli şartları taşıdığına karar vermiştir. Böylece 2008-2009 Eğitim-Öğretim Yllından itibaren Almanca Mezhep Merkezli Alevilik Din Dersleri önce ilkokullarda, daha sonra da ortaokullarda (2012) verilmeye başlanmıştır (Kiefer, 2009). ${ }^{1}$

Günümüzde Alevi ve İslam din dersleri Federal Almanya Anayasası'nın 7. maddesinin 3. fıkrasına göre örgün eğitim kurumlarında okutulan zorunlu (düzenli) dersler arasında yer almaktadır. Her iki ders de Alman dilinde verilmekte, not ile değerlendirilmekte ve sınıf geçmeye etki etmektedir (Deutscher Bundestag, 2007).

Araştırmanın temel problemi, "Almanya'nın Kuzey Ren-Vestfalya Eyaletinde uygulanmakta olan Alevilik ile İslam din dersi öğretim programlarının karşılaştırılması" olarak belirlenmiștir. Araştırmanın alt problemleri ise şunlardır:

a. Öğretim Programlarında Benimsenen Yaklaşımlar Hangileridir?

b. Öğretim Programlarının Temel Hedefleri Nelerdir?

c. Öğretim Programları Nasıl Yapılandırılmıştır?

d. Öğretim Programlarında Nasıl Bir İçerik Sunulmaktadır?

e. Öğretim Programlarının Genel Kazanımları Nelerdir?

f. Ölçme ve Değerlendirme Nasıl Yapılmaktadır?

Çalışmanın amacı, Almanya'nın Kuzey Ren-Vestfalya Eyaletinde

1 Alevilik din dersi öğretim programlarına ilișkin analiz ve değerlendirmeler için bkz: Tosun, C. ve Zengin, H. K. (2009). Almanya'daki Alevilik Din Dersi Programları (1.-4. Sınıflar) Üzerine Bir İçerik Analizi. Dini Araştırmalar Dergisi, 12 (33), 345-380. 
uygulanmakta olan Alevilik Din Dersi Öğretim Programı ile İslam Din Dersi Öğretim Programını karşılaștırmak, aralarındaki benzerlik ve farklılıkları ortaya koymaktır. Buna göre her iki öğretim programının dayandığı temel yaklaşım, amaç, içerik, ölçme ve değerlendirme durumları incelenmiş, elde edilen verilerden hareketle değerlendirilmiştir.

Bu konuda daha önce yapılan çalışmalar, bahsi geçen öğretim programlarının birbirinden bağımsız olarak incelendiği, aralarında herhangi bir karşılaştırmanın yapılmadığı çalışmalardır (bkz: Tosun, C. ve Zengin, H. $\mathrm{K}, 2009)$. Bu çalışma ise her iki öğretim programının dayandığı temel yaklaşımın, hedeflerin, ders konularının, ölçme ve değerlendirme boyutlarının karşılaştırılması; aralarındaki benzerlik ve farklılıkların birlikte ele alınıp analiz edilmesi esasına dayanmaktadır. Bu yönüyle bir ilk olma özelliği taşıyan çalışmanın, din eğitim ve öğretiminde program geliştirme çalışmalarına önemli bir katkı sağlayacağı ve farklı bir bakış açısı sunacağı düşünülmektedir. Ayrıca farklı ülkelerde uygulanmakta olan öğretim programlarının incelenmesi, iyi örneklerin alana taşınması, öğretim programı geliştirme ve dönüştürme çalışmalarına katkı sağlaması açısından da önemli görülmektedir.

\section{A. Yöntem}

Çalışmada nitel araştırma yöntemlerinden doküman incelemesi kullanılmıștır. Doküman incelemesi, araştırılması hedeflenen olgu/olgular hakkında bilgi içeren yazılı materyallerin (belge, günlük, mektup, doküman, öğretim programı, ders kitabı vb.) belli kriterlere göre incelenmesi ve analiz edilmesi esasına dayanmaktadır (Yıldırım, A. \& Şimşek, H., 2016). Buna göre çalışmada, hem Alevilik Din Dersi Öğretim Programı hem de İslam Din Dersi Öğretim Programı incelenmiş, çeşitli parametreler/değişkenler (eğitimöğretim yaklaşımları, temel hedefler, yapı ve içerik, kazanımlar, ölçme ve değerlendirme) açısından karşılaştırılmıştır. İnceleme sonucunda elde edilen veriler benzerlik ve farklılık ölçütlerine göre gruplandırılmış, öğretim programları arasındaki farklar, elde edilen bulgulardan hareketle yorumlanmıştır.

İnceleme sürecinde her iki program baştan sona okunmuş ve gerekli kodlamalar yapılmıştır. Kodlama için problem ve alt problemler dışında önceden herhangi bir kategori belirlenmemiștir. Okuma esnasında yapılan kodlamalara göre oluşturulan kategoriler şunlardır:

a. Öğretim Programlarına Temel Olan Yaklaşımlar.

b. Öğretim Programlarının Temel Hedefleri.

c. Öğretim Programlarının Yapısal Özellikleri ve Konu İçeriği. 
d. Öğretim Programlarının Genel Kazanımları.

e. Öğretim Programlarının Ölçme ve Değerlendirme Boyutu.

Araştırmada incelenen doküman, Almanya'nın Kuzey Ren-Vestfalya Eyaleti Eğitim Bakanlığı tarafından 2013 yılında yayımlanan Alevilik Din Dersi Öğretim Programı (1-4. Sınıflar) ile yine aynı bakanlık tarafından 2014 yılında yayımlanan İslam Din Dersi Öğretim Programıdır (1-4. Sınıflar). Çalışmada Kuzey Ren-Vestfalya Eyaleti öğretim programlarının tercih edilmesinin başlıca nedeni, söz konusu eyaletin Almanya'da en yoğun Müslüman nüfusa $(1.485,344)$, bir başka ifadeyle en yoğun Müslüman öğrenci nüfusuna sahip olmasıdır (Muslimisches Leben in NordrheinWestfalen, 2010; Statista, 2019). Federal Göç ve Mülteciler Dairesi tarafından 2009 yılında yapılan bir araştırmaya göre, Almanya'da bulunan her üç Müslümandan birisi bu eyalette yaşamaktadır. Kuzey Ren-Vestfalya Eyaletini sirasiyla Baden-Württemberg, Bayvera und Hessen eyaletleri izlemektedir (BAMF, 2009).

\section{B. Bulgular}

Bulgular başlığı altında her iki program da incelenmiş, elde edilen veriler analiz edilerek değerlendirmeye tabi tutulmuştur. Ayrıca bu programlar, temel alınan yaklaşım, hedefler, yapısal özellikler, konu içeriği, genel kazanımlar, ölçme ve değerlendirme boyutları açısından karşılaştırılmıştır.

\section{Alevilik ile İslam Din Dersi Öğretim Programlarında Temel Olan Yaklaşımlar}

a. Alevilik Din Dersi Öğretim Programında Temel Alınan Yaklaşım

Programda, din dersinde benimsenen didaktik yaklaşımın ne olduğuna doğrudan değinilmemektedir. Ancak programda yer alan, "öğrencilerin gerçek yaşamları ile Alevilik geleneğini bir araya getirmek, aralarında ilişki kurmak..." amaç ifadesinden, programın korelasyon didaktiği yaklaşımı temel alınarak hazırlandığı anlaşılmaktadır (MSB, 2013). Korelasyon didaktiği, din öğretiminde dini bilgi (dini gelenek) ile öğrencilerin gerçek yaşamlarını (deneyim ve tecrübe) dikkate alma ve bu ikisi arasında ilişki kurma ve/veya var olan ilişkiyi ortaya çıkarma düşüncesiyle geliştirilmiş bir din öğretimi yaklaşımıdır. Öğrencilerin gerçek yaşamları, deneyim ve tecrübeleri ile Alevilik geleneği arasında ilişki kurulması ve/veya var olan ilişkininin ortaya çıkarılması ilkesi programın genelinde dikkate alınmaktadır. Öğretim programında gerçek hayatla ilișkilendirilmeyen (hayatilik ilkesi) dini bilginin (dini gelenek ve tecrübe) 
belirtilmektedir (MSB, 2013).

Programda Alevilik kimlik gelişiminin destekleniyor olması, ayrıca öğrencilere Alevi geleneğine dayalı bilgi, tutum ve becerilerin kazandırılmak istenmesi (MSB, 2013), bu programda Mezhep Merkezli Din Öğretimi Yaklaşımının benimsendiğini de göstermektedir. Mezhep Merkezli Din Öğretimi Yaklaşımı, tek ve belirli bir dinin/mezhebin öğretilmesi, öğrencilerin mensubu oldukları dinin/mezhebin inanç esaslarını bilmesi ve bununla barıșık olması ilkesine dayanmaktadır (Asbrand, 1999). Mezhep Merkezli Din Öğretimi Yaklaşımının temel hedefi, öğrencilerin dindar bireyler olarak yetişmeleri, dini ritüel (ibadet) ve seremonilere katılmaları için gerekli tüm önlemlerin alınmasıdır (Heckel, 2005). Programda diğer inanç sistemleri, bir başka ifadeyle din (Hristiyanlık, Yahudilik) ve mezheplere (Katoliklik, Protestanlık vb.) ilişkin bilgilere de yer verilmektedir (MSB, 2013). Bu durum, programın bir yönüyle "Mezhep Merkezli Dinler Arası Açlımlı” özellikte olduğunu da göstermektedir. Benzer bir sonuca, Tosun ve Zengin'in (2009) “Almanya'daki Alevilik Din Dersi Programları (1.-4. Sinıflar) Üzerine Bir İçerik Analizi" adlı çalışmasında ulaşılmıştır. Söz konusu çalışmada da, Alevilik Din Dersi Öğretim Programının mezhep merkezli özellikte olduğu tespit edilmiştir. Programda diğer mezhep ve dinler hakkında bilgi veriliyor olması ise, programın mezhep ve dinler arası açılımlı olduğu şeklinde değerlendirilmiştir. Ancak bu durum, dersin temel niteliği olma bakımından ikincil bir özellik olarak yorumlanmıştır.

\section{b. İslam Din Dersi Öğretim Programında Temel Alınan Yaklașım}

Din dersi, İslam dininin temel inanç esasları dikkate alınarak verilmektedir. Söz konusu inanç esaslarının başında da Allah'a ve Hz. Muhammed'e iman gelmektedir. Öğrencilerden İslam inanç, ibadet ve ahlak ilkelerini bilmesi, bunlar üzerinde tefekkür etmesi (düşünmesi) ve bunları hayata geçirmesi beklenmektedir. Dersin temel gayesi öğrencilere İslam dini hakkında bilgi vermek, İslam dinini sevdirmek; öğrencileri İslam dini ve İslam dininin insan hayatındaki yeri ve önemi konusunda aydınlatmaktır (MSB, 2014). Programda yer alan bu ve benzeri açıklamalardan, İslam Din Dersi Öğretim Programının Mezhep Merkezli Din Öğretimi Yaklaşımı temel alınarak geliştirildiği anlaşılmaktadır.

Öğretim programında farklı inanç sistemlerine, din ve mezheplere ilişkin konulara da yer verilmektedir. Öğrencilerden diğer dinleri tanımaları, diğer din mensuplarına saygı göstermeleri ve onlarla iyi ilişkiler geliştirmeleri istenmektedir (MSB, 2014). Buna göre, öğretim programının - 
mezhep merkezli olmakla beraber- dinler arası açılımlı bir anlayışa sahip olduğu da söylenebilir. Mezhep Merkezli Dinler Arası Açılımlı Din Öğretimi Yaklaşımının temelini yine mezhep merkezli din dersi anlayışı oluşturmaktadır. Bununla beraber diğer din ve mezheplerle ilgili bilgilere de yer verilmektedir. Bu yaklaşımın temel hedefi, öğrencilerin farklılıklar içinde -farklı inanç sistemi ve dini dünya görüşüne sahip insanlarla- bir arada yaşamayı öğrenebilmeleridir (Tosun, 2015).

Öğrencilerin eğitim-öğretim sürecinde aktif olmaları, kendi deneyim ve tecrübelerini öğrenme ortamına taşımaları istenmektedir. İslam Din Dersi, dini geleneğin salt aktarımından ziyade, bunların öğrencilerin gerçek yaşamlarıyla ilişkilendirilmesini öngörmektedir. Öğrencilerden, din dersinde kazandıkları dini bilgi ile gerçek yaşamlarını, bir başka ifadeyle edindikleri deneyim ve tecrübeleri bir araya getirmeleri, aralarındaki ilişkiyi ortaya çıkarmaları beklenmektedir (MSB, 2014). Öğretim programının, bu yönüyle Korelasyon Didaktiği Yaklaşımı temel alınarak hazırlandığı da ifade edilebilir.

\section{Alevilik İle İslam Din Dersi Öğretim Programlarının Temel}

\section{Hedefleri}

\section{a. Alevilik Din Dersi Öğretim Programının Temel Hedefleri}

Alevilik Din Dersi Öğretim Programının temel hedefi, öğrencilerin içinde doğup büyüdükleri çevreyi (Aleviliği) anlamaları ve bunun için gerekli olan bilgi ve becerileri kazanmalarıdır. Öğretim programının bir diğer hedefi ise öğrencilerin Alevilikle ilgili temel kavramları öğrenmeleri, Aleviliğe dair olumlu bir anlayış geliştirmeleridir. Buna göre öğretim programının temel hedefleri;

a. Alevi öğrencilerin kimlik gelişimini desteklemek,

b. Öğrencilerde Aleviliğe, onun tarihine ve günümüzdeki durumuna ilişkin farkındalı̆̆ı arttırmak,

c. Öğrencilere kendi hayatlarını düzenlemede rehberlik etmek,

d. Öğrencilerin dil gelişimini, özellikle Alevilikle ilgili temel kavramlar ve bunlarla ilişkili metaforlar bağlamında desteklemek,

e. Öğrencileri Aleviliğin temel kaynaklarına dayanan bir yaşam biçimine, tutum ve davranışlara motive etmek,

f. Alevi öğrencilerin diğer din mensuplarıyla bir arada barıș, eşitlik ve karşılıklı saygı temelinde yaşamalarını desteklemektir (MSB, 2013).

$\mathrm{Bu}$ açıklamalardan da anlaşılacağı üzere dersin temel hedefi, 
öğrencilerde Alevi inanç ve kültürünün geliştirilmesi; diğer bir ifadeyle öğrencilerin Aleviliğin ne olduğunu bilmeleri, Alevilik kimliğine sahip olmaları ve buna uygun bir yaşam sürmeleridir. Söz konusu bulgularla benzerlik göstermesi açısından Tosun ve Zengin'in (2009) "Almanya'daki Alevilik Din Dersi Programları (1.-4. Sınıflar) Üzerine Bir İçerik Analizi" adlı çalışmada ulaştıkları sonuçlar dikkat çekicidir. Zira Tosun ve Zengin'in araştırma bulgularında da, Alevilik Din Dersi Öğretim Programının genel görev ve hedeflerinin, öğrencilerde Alevi kimlik gelişiminin desteklenmesi, Alevilikle ilgili inanç, değer, ritüel ve geleneklerin kazandırılması, öğrencilerin Aleviliğe uygun bir yaşam sürmeleri için gerekli önlemlerin alınması olduğu sonucuna ulaşılmıștır.

Dersin bir başka hedefi ise farklı etnik kökene ve dini aidiyete sahip öğrencilerin birbirlerine saygı duymalarını mümkün kılacak kültürlerarası öğrenme ortamını sağlamaktır. Programda, Aleviliğin yazılı (temel) kaynaklarından Buyruk'ta geçen, "72 Millete (Bütün İnsanlara) Aynı Nazarla Bakmak" ilkesinin, söz konusu hedefe ulaşmada benimsenen en temel anlayış olduğu ifade edilmektedir (MSB, 2013).

\section{b. İslam Din Dersi Öğretim Programının Temel Hedefleri}

İslam Din Dersi Öğretim Programının temel hedefi, öğrencilerin İslam dininin inanç esaslarını, ahlaki ve ameli hükümlerini bilmeleri ve kendi yaşamlarını düzenlemede bunları dikkate almalarıdır (MSB, 2014). Programın diğer hedefleri ise şunlardır:

1. Toplumun birer üyesi olan, toplumun değişim ve gelişiminde aktif rol oynayan öğrencileri yaşam serüvenlerinde desteklemek.

2. Öğrencilerin dine ve dini olana karşı sorumluluk bilinciyle yaklaşmalarını sağlamak (talim, terbiye ve te'dîb yoluyla).

3. Öğrencilere varoluşsal soru ve sorunların üstesinden gelmede; Nereden geldim, nereye gidiyorum? Hayatın ve insan olmanın gayesi nedir? vb. sorularını cevaplandırmada yardımcı olmak.

4. Öğrencileri tutum ve davranışlarını düzenlemede/geliştirmede İslam'ın temel kaynaklarına (Kur'an, Sünnet) motive etmek.

5. Öğrencilerin dil gelişiminde İslam kültüründen ve metaforik üslup geleneğinden yararlanmalarını sağlamak.

6. Öğrencilerin hem İslam dinini hem de İslam geleneğini aktif ve yansıtıcı bir biçimde ele almalarını mümkün kılmak.

7. Öğrencilerin din içi ve din dışı çeşitliliği (çoğul yapıyı) kavramalarına, çeşitliliğin taşıdığı anlam ve değere duyarlılık 
geliştirmelerine yardımcı olmak.

8. Öğrencilerin toplum-birey etkileşiminin (özellikle toplu halde yapılan ritüeller/ibadetler bağlamında) farkında olmalarını sağlamak.

9. Öğrencilerin farklı din ve dünya görüşüne sahip insan ve topluluklarla iletişim kurma; hoşgörü ve saygı iklimi geliştirme çabalarını desteklemek.

İslam Din Dersi Öğretim Programı incelendiğinde öğrencilerin, kendilerinde İslam dinine ilişkin bilgi, beceri, tutum ve davranış geliştirmelerinin ve bunları kendi yaşamlarını düzenlemede işe koşmalarının hedeflendiği görülmektedir. Programda, öğrencilerin farklı dini aidiyete ve dünya görüşüne sahip insanlarla bir arada yaşamalarının, toplumsal ilişkilerde saygı ve sevgi iklimini tesis etmelerinin hedeflendiği de anlaşılmaktadır.

\section{Din Dersi Öğretim Programlarının Yapısal Özellikleri ve Konu} İçeriği

a. Alevilik Din Dersi Öğretim Programının Yapısal Özelliği ve Konu İçeriği

Alevilik Din Dersi Öğretim Programı "İnsanın Doğa, Teknoloji ve Tarihle Olan İlişskisi”, "İnsanın Diğer İnsanlarla Olan İlișkisi”, "İnsanın Kendisiyle Olan İlişkisi", "İnsanın Tanrı ve Dinlerle Olan İlişkisi” olmak üzere dört öğrenme alanı ve bu öğrenme alanlarını oluşturan üniteler halinde düzenlenmiştir. Öğrenme alanında yer alan ünitelerin düzenlenmesinde tematik yaklaşım temel alınmıştır. Bununla, öğrencilerin gündelik yaşamları ile Alevilik öğretisi ve geleneği arasındaki ilişkinin (korelasyonun) ortaya çıkarılması hedeflenmiştir (MSB, 2013).

Öğretim programı 28 üniteden oluşmaktadır². Programda, farklı sınıf düzeylerinde yer alan üniteler birbirinden bağımsız değerlendirilmemekte,

2 Alevilik Din Dersi Öğretim Programında Yer Alan Üniteler Şunlardır: 1. Sınıf: "Kendimizi Tanıyoruz", "Ailem", "Cemevi", "Yol Bulmak", "Hak-Muhammed-Ali Yolu- Tek Bir Yol", "Bana Yardım Et Hızır", "Alevilikte Yer Alan Dini Bayramlar-Ali'nin Doğum Günü ve Nevruz". 2. Sınıf: "Ben ve Diğer İnsanlar", "Oynamak ve Öğrenmek, Öğrenmek ve Oynamak", "Semah- Dans mı, Ritüel mi, İbadet mi?”, “Ben ve Bedenim”, “Tanrı'nın Dünyayı ve Yaşamı Yaratması", "Hacı Bektaş-ı Veli ve Doğa”, "İnsanlar Nasıl ve Neden Kutlama Yapar". 3. Sınıf: Yardım Almak Yardımda Bulunmak-Dostluk", "Muharrem Orucu ve Matem Günleri", "Lokma”, "Ehli Beyt-Kurbanlar ve Rol Modeller", "Matem- Umut Nedeni”, "Oniki İmam- Aleviliğin Başlangıcı", "Dini Günleri Kutluyoruz- Aşure”. 4. Sinıf: "Dikkate Almak", "Kuralsız Oyun Olmaz", "Çatışma ve Anlaşmazlık Durumlarının Çözümü”, "Cem Yolunu Bulmak", “Oniki Hizmet, Görev ve Ritüel”, "Müslümanlar, Hristiyanlar ve Yahudiler", "Hacı Bektaş-ı Velinin Varlığını Kutluyoruz”. 
belli bir ünite veya konu işlenirken diğer ünite ve/veya konular da göz önünde bulundurulmaktadır. Belli bir sınıf düzeyinde ünite ve konularının ele alınmasında herhangi bir sira takip etme zorunluluğu da bulunmamaktadır. Didaktik gerekçeler konular arası geçişler için yeterli görülmektedir (MSB, 2013).

Üniteler üç kategori altında toplanmıştır. Bunlar; "İnsanlar", "İstikamet (Yol)" ve "Ev ve Düzen" kategorileridir. İnsanlar Kategorisinde Aleviliğin ve bildirmiş olduğu esasların öğrencilerin gerçek yaşamlarından, deneyim ve tecrübelerinden hareketle ortaya çıkarılıp açıklığa kavuşturulması istenmektedir (İndüktif Korelasyon). İstikamet (Yol) Kategorisinde öğrencilerin yaşadıklarını, deneyimlediklerini ve tecrübe ettiklerini anlayıp anlamlandırmalarında Aleviliğe ve onun bildirdiklerine başvurulması söz konusudur (Dedüktif Korelasyon). Ev ve Düzen Kategorisinde ise Alevilik ile gerçek hayat arasında zaten var olan ilişkinin ortaya çıkartılması beklenmektedir (Abdüktif Korelasyon). Çalışmamızın “Alevilik Din Dersi Öğretim Programının Yapısal Özelliği ve Konu İçeriği”ne ilișkin bulgularının, Tosun ve Zengin'in (2009) “Almanya'daki Alevilik Din Dersi Programları (1.-4. Sinıflar) Üzerine Bir İçerik Analizi" adlı çalışmalarından elde edilen bulgularla benzerlik gösterdiği saptanmıştır. Söz konusu çalışmada da öğretim programının 28 üniteden oluştuğu, ünitelerin "İnsanlar", "İstikamet (Yol)" ve "Ev ve Düzen” olmak üzere üç kategoride toplandığı sonucuna ulaşılmıştır.

Ünitelerin söz konusu kategoriler altında düzenlenmiş olmasının başlıca nedeni, din dersine konu olan dini bilgi ve gelenek ile derse katılan öğrencilerin yaşamları, deneyim ve tecrübeleri arasındaki ilişkinin kurulması, mevcut ilişkinin gün yüzüne çıkartılmasıdır. Öğretim programının temel hedefi, hayatın gerçekleri ile Alevi toplumunun benimsediği öğreti ve sahip olduğu gelenek arasındaki korelasyonun eğitimöğretim yoluyla ortaya konulması; Aleviliğin gerçek yaşamda, yaşanılan hayatın da Alevilikte din öğretimi yoluyla somut bir karşılık bulmasıdır (MSB, 2013).

Öğrenme Alanlarını oluşturan ünitelerin başında "Hak-MuhammedAli” ünitesi gelmektedir. Burada, Alevilik inanç sisteminde önemli bir yere sahip olan Hak-Muhammed-Ali inancına/üçlemesine, Alevilerin Hz. Ali ve Hz. Muhammed'e verdikleri öneme değinilmektedir. Öğrenme alanlarını meydana getiren bir diğer ünite "Cemevi" ünitesidir. Bu ünitede öğrencilerden cemevlerinin yapısal özelliklerini bilmeleri, buralarda düzenlenen törenlerin anlam ve önemini kavramaları, cem törenlerine 
katılan insanların neler hissettiklerini keşfetmeleri istenmektedir. Programda cemevlerinin birer ibadethane olduklarından söz edilmekte, özellikle cami ve kilise ile karşılaştırılmaktadır. Öğretim programında yer alan bir diğer konu dini gün ve gecelerdir. Burada Nevruz Bayramına, Muharrem Ayı ve Orucuna, Aşure Gününe; sözü edilen gün ve gecelerde nelere dikkat edilmesi gerektiğine değinilmektedir. Öğretim programında öne çıkan bir diğer konu Ehl-i Beyt ve onun örnekliğidir. Öğrencilerden, Hz. Muhammed'i, Hz. Ali'yi ve Ehl-i Beyt'i tanımaları, Aleviler için taşıdığı anlam ve önemi fark etmeleri, bunların Aleviler üzerindeki etkilerini incelemeleri ve kendileri için çıkarımda bulunmaları (örnek almaları) istenmektedir (MSB, 2013).

Öğretim programında diğer inanç sistemlerine, din ve mezheplere ilişkin bilgilere de yer verilmektedir. Burada, Alevilik dışındaki inanç sistemlerinin öğrenciler tarafından bilinmesi; Aleviliğin diğer din ve mezheplerle karşılaştırılması, aralarındaki benzerlik ve farklılıkların ortaya konulması üzerinde durulmaktadır. Programda, dini veya kültürel ritüellerin (Hızır-Nikolaus veya Aşure-Paskalya) farklı dinlere mensup öğrencilerle birlikte kutlanması, dinlerarası etkileşim ve bilgi paylaşımı için bir fırsat olarak değerlendirilmektedir. Pedagojik ilkelere uygun olan, cami, kilise ve sinagog ziyaretlerinin öğrenciler arası ilişkilere, barış ve huzur iklimine katkı sağlayacağı ifade edilmektedir (MSB, 2013).

Öğretim programı, Alevi kültür ve felsefesinden, ayin (ritüel) ve törenlerden ve elbette sembollerden hareketle geliştirilen eserler temel alınarak hazırlanmıştır. Özellikle cem toplantılarının vazgeçilmez bir parçası olan Hatayi, Pir Sultan Abdal ve Kul Himmet'in deyiş ve nefesleri Alevilik dersinin temel kaynakları arasında yer almaktadır. Alevilik Din Dersinin diğer temel kaynakları ise; "Hz. Ali'ye isnad edilen ve çeşitli metinlerden oluşan Nehcü’l Belâğa”, "Hacı Bektaş-ı Velinin hayatı ile ilgili anektodların bulunduğu Velayetname”, "Ana konusu Alevilik inancındaki 'dört kapı ve kırk makam' olan Makalat", "Yedi Ulu Ozan'ın (Seyyid Nesimi, Fuzuli, Hatayi, Pir Sultan Abdal, Kul Himmet, Yemini ve Virani) şiirleri" ile "Hallacı Mansur, Yunus Emre, Balım Sultan, Hilmi Baba ve Âșlk Veysel'in eserleri”dir (MSB, 2013).

b. İslam Din Dersi Öğretim Programının Yapısal Özelliği ve Konu İçeriği

İslam Din Dersi Öğretim Programı altı öğrenme alanı ve bu öğrenme alanlarını oluşturan üniteler halinde düzenlenmiștir (MSB, 2014). Bunlar;

- Allah - Her Șey Ondan Gelir ve Yine Ona Döner, 
- Allah'ın Yaratması ve İnsan Topluluğu (Beşeriyet),

- Peygamberler ve Allah'ın Son Elçisi Hz. Muhammed,

- Kutsal Kitaplar ve Allah Kelamı Kur'an-ı Kerim,

- Dinin İnsan Hayatındaki Yeri ile

- Dünya Hayatı ve Sorumluluk Bilinci öğrenme alanlarıdır.

Allah - Her Şey Ondan Gelir ve Yine Ona Döner öğrenme alanı,"Allah'ın Varlığı ve Birliği (Tevhid)", "Temel İnanç Esasları" ve "İnsanın Anlam Arayışı" üniteleri etrafında şekillenmektedir. Burada Kur'an ve Sünnette geçen yaratılış öyküsü, tevhid inancı ve diğer dinlerdeki tanrı tasavvuru ele alınmaktadır. Öğrencilerin tevhid inancına sahip olmaları, yaşamlarını söz konusu inanç temelinde düzenlemeleri (kendileri için çıarımda bulunmaları), Allah'a ve Allah'ın yarattıklarına karşı görev ve sorumluluklarının bilincinde olmaları gerektiği vurgulanmaktadır. Öğrenme alanında özellikle Allah'ın varlığının ve birliğinin izlerine (delillerine) ve O'nunla iletişime geçme yollarına yer verilmektedir (MSB, 2014).

Allah'ın Yaratması ve İnsan Topluluğu (Beşeriyet) öğrenme alanı "Allah Tarafından Yaratılan İnsan", "Birlikte Yaşamanın Yolları" ve "İslam Toplumu (Ümmet)" ünitelerinden oluşmaktadır. Burada İslam dininin insanların birlik ve beraberliğine büyük bir önem verdiği; insanlar arasındaki farklılıkların birer zenginlik olduğu, bütün insanların tek bir Tanrı tarafından yaratıldığı ve aynı önem ve değere sahip oldukları vurgulanmaktadır. Öğrencilerden, kendilerinde toplumsal birlik ve beraberlik için gerekli olan tutum ve davranışları geliştirmeleri, diğer din mensuplarıyla iyi ilişkiler kurmaları istenmektedir. Öğrencilerin diğer insanlarla (din mensuplarıyla) ilişki kurmalarl; dini kimliklerini kazanmalarına, kendi kişiliklerini keşfetmelerine ve bunları geliştirmelerine destek olması bakımından önemli bulunmaktadır. Böylece öğrencilere içinde doğup büyüdükleri toplumun (ümmetin) birer parçası olma firsatı da sunulmaktadır (MSB, 2014).

Peygamberler ve Allah'ın Son Elçisi Hz. Muhammed öğrenme alanında "İnsanlar İçin Örnek Şahsiyetler (Rol Model)", Tanrı'nın Elçileri Olarak Peygamberler" ve "Bir Peygamber ve İnsan Olarak Hz. Muhammed" üniteleri bulunmaktadır. Burada peygamberlerin örnek kișiliğine ve bunların inanan insanlar üzerindeki etkilerine değinilmektedir. Öğrencilerden peygamberleri örnek alıp onlara tabi olmaları, peygamberlerin yaşamları (biyografi) ile kendi deneyim ve tecrübeleri arasında ilişki kurmaları, peygamberlerin beşeri özelliklerinden kendi tutum ve davranışları için 
çıkarımda bulunmaları istenmektedir. Peygamberlerin yanı sıra önemli tarihi karakterlere de (rol model) yer verilmekte, bunların olgu ve olaylar karşısında takındıkları tutum ve sergiledikleri davranışlara yer verilmektedir (MSB, 2014).

Kutsal Kitaplar ve Allah Kelamı Kur'an-ı Kerim Öğrenme Alanı, "Ilk Vahiy ve Tebliğ", "Kur'an'ın Yapısal (Estetik) Özellikleri”, "Bir Kitap Olarak Kur'an" ve "Kur'an'dan Önceki Kutsal Kitaplar" ünitelerinden meydana gelmektedir. Burada Kuran-ı Kerim'in Allah tarafından gönderilen son ilahi kitap olduğuna ve kendinden önceki ilahi kitapları tasdik ettiğine/doğruladığına değinilmektedir. Öğrencilerden Kur'an-ı Kerim'le iştigal etmeleri ve bunu yaparken diğer ilahi kitapları da göz önünde bulundurmaları istenmektedir. Öğrenme alanında Kur'an-ı Kerim'in yanı sıra Tevrat, Zebur ve İncil'e de yer verilmektedir. Söz konusu kutsal kitapların ilahi kaynaklı olmakla beraber nesh edildikleri ifade edilmektedir. Kur'an-ı Kerim'in nazil olma (indirilme ve tamamlanma) süreci, muhtevası ve yapısal özellikleri öğrenme alanında ele alınan diğer konulardır (MSB, 2014).

Dinin İnsan Hayatındaki Yeri öğrenme alanı, "Allah İnancını Dile Getirmek", "Müslümanların İbadet Ettikleri Mekânlar" ve "Toplumda Kutlanan Dini Gün ve Geceler" ünitelerinden meydana gelmektedir. Burada İslam'ın beş şartı, ibadet edilen mekânlar ve dini gün ve geceler ele alınmaktadır. Öğrencilerden dini hayatı fark etmeleri, ibadet türlerini ve bunlarla ilgili esasları bilmeleri; İbadetlerin Allah'a yakınlaşmadaki, O'nunla iletişim kurmadaki rolünü fark etmeleri beklenmektedir. Bu alanda öğrencilerden, diğer dinlerde Tanrı'ya tâzimi ve şükrü ifade etmek için yapılan ibadetlere hoşgörüyle yaklaşmaları, Tanrı'ya dua eden bütün insanlarla manevi bir bağ kurmaları ve onlara saygı duymaları istenmektedir. Müslümanların İbadet Ettikleri Mekânlar ünitesinde cami ve mescidlerin tarihsel gelişimi, özellikleri, dini ve toplumsal işlevi ele alınırken bunların birer toplanma, bir araya gelme mekânları oldukları belirtilmektedir. Ayrıca cami ve mescidler ile diğer dinlerdeki (Yahudilik ve Hırstiyanlık) ibadethaneler arasında ilişki kurulmakta; öğrencilerin semavi dinlerin ortak yönlerini görmeleri ve karşıllklı öğrenmeyi sağlamaları hedeflenmektedir. Dini Gün ve Geceler ünitesinde ise bayramların, sözü edilen gün ve gecelerin hem bireysel hem de toplumsal hayattaki karşılığı ele alınmaktadır (MSB, 2014).

Dünya Hayatı - Sorumluluk Bilinci Öğrenme Alanı "Yaratılışa Karşı Sorumluluk" ve "Birlikte Saygı Temelinde Yaşamak" ünitelerinden oluşmaktadır. Öğrencilerden, yaratılmış olmayı bir lütuf ve armağan olarak 
değerlendirmeleri ve sorumluluk bilinciyle hareket etmeleri istenmektedir. Burada hayatın dini boyutunun keşfedilmesine, birlikte yaşama kültürü oluşturulmasına ve insan onurunun gözetilmesine dönük konulara yer verilirken; öğrencilerin farklı yaşam tarzlarına, ideolojilere, dini ve/veya dini olmayan dünya görüşlerine sahip insanlara saygı duymalarını destekleyecek konulara değinilmektedir (MSB, 2014).

\section{Alevilik İle İslam Din Dersi Öğretim Programlarının Genel Kazanımları}

\section{a. Alevilik Din Dersi Öğretim Programının Genel Kazanımları}

Alevilik Din Dersi Öğretim Programında kazanımlar üç öğrenme alanı altında düzenlenmiştir. Bunlar bilişsel (bilgi), duyuşsal (duygu) ve psikomotor (fiziksel beceri) öğrenme alanlarıdır. Bilişsel alan, zihinsel öğrenmelerin çoğunlukta olduğu, zihinsel becerilerin geliştirilmeye çalışıldığı bir alandır. Duyuşsal alan, duygusal tarafın (sevgi, korku, tutum, nefret, ilgi vb.) baskın olduğu alandır. Devinişsel alan ise, daha çok fiziksel becerilerin baskın olduğu bir öğrenme alanıdır (Demirel, 2000).

Öğrencilerde geliştirilmeye çalışılan becerilerin başında bilişsel alan öğrenme kazanımları gelmektedir. Buna göre öğrencilerden;

a. Alevilikteki tanrı tasavvuru (Allah, Hak, Hüda),

b. Alevilik düşüncesindeki Hak-Muhammed-Ali ilişkisi,

c. Alevilik inanç esasları ve Alevi değerleri,

d. Aleviliğin tarihsel ve manevi temelleri,

e. Alevi kültürü ve bu kültürün bazı unsurlarının (ilahi, saz, semah vb.) dini tören ve ayinlerle olan ilişkisi,

f. Alevi etik ve ahlak anlayışının temelleri,

g. Aleviliğin cem, semah gibi dini formları, Alevi tutum ve davranışlarının ifade biçimi (metaforik üslup),

h. Hz. Muhammed, Hz. Ali ve Oniki İmam ile ilgili hikâyeler/rivayetler,

i. Kutsal/Aziz Hacı Bektaş-ı Veli ve diğer kutsalların/azizlerin (Yedi Ulu Ozan) anlam ve önemi,

j. Büyük dinlerdeki diğer peygamberler,

k. Alevi olmayan sınıf arkadaşlarının tabi oldukları inanç sistemleri (din) ile inanç yönelimleri hakkında bilgi sahibi olmaları beklenmektedir (MSB, 2013).

Öğretim programında öğrencilere kazandırılmak istenen tutum ve davranış biçimlerine, bir diğer ifadeyle duyuşsal alan öğrenme 
kazanımlarına da yer verilmiştir (MSB, 2013). Buna göre öğrenciler,

a. Aleviliğin hem tarihsel hem de bölgesel anlamda çok farklı ve çeşitli șekillerde yaşandığını kabul eder.

b. Farklı inanç sistemleri ve dünya görüşüne sahip insanlara saygı duymaya istekli olur.

c. Olumlu bir kişilik geliştirmeyi ve kendilerine başkalarının gözünden eleştirel bakabilmeyi arzu eder.

d. Adil tutum ve davranışlar için sorumluluk almaya rıza gösterir.

e. Haksızlık karşısında medeni cesaret göstermeye istekli olur.

f. Sahip oldukları anlayış ve davranış biçimini gözden geçirmeye ve gerektiğinde bunları değiştirmeye rıza gösterir.

g. Alevilik inanç esaslarının aile, okul ve diğer yaşam alanlarında uygulanabilirliğini gözden geçirmeye ve bunları hayata geçirmeye istekli olur.

h. Farklı cemaat ve cemiyetlerde (Alevi toplumu ve seküler topluluklar) sorumluluk bilinciyle hareket etmeye ve ahlaki davranış geliştirmeye hazır olur.

i. Yaratılanlara karşı duyarlı/hassas ve sorumluluk bilinciyle yaklaşmaya istekli olur.

Alevilik Din Dersi Öğretim Programında öğrencilerde geliştirilmek istenen psiko-motor (fiziksel beceriler) alan öğrenme kazanımları ise şunlardır:

a. Aleviliği, hem içerik hem de uygulama boyutuyla mevcut inanç ve yaşam biçiminin bir ifadesi olarak algılamak.

b. Kendi inanç, gelenek ve kültürünü diğer din/inanç mensubu arkadaşları karşısında temsil etmek, kendisi dışındakilere saygıyla yaklaşmak ve onları anlamaya çalışmak.

c. Farklı din ve dünya görüşüne sahip insanlarla olumlu ilişkiler kurmak.

d. Kendi duygularını ve yaşam deneyimlerini dile getirmek ve bunları diğer insanların duygu ve deneyimleriyle karşlaştırmak.

e. Alevi geleneğini kendi gerçekliğinde incelemek ve gerektiğinde bunları entegre/optimize etmek.

f. Kuralları bilmek, bu kuralların anlamlı olup olmadıklarını sınamak ve gerektiğinde Alevilikteki rızalık anlayışı bağlamında dönüştürmek. 
g. Çatışma durumlarını Alevilikteki rızalık anlayışıyla aşmak.

h. Nesnelerin ve hayatın anlamını; ayrıca insanların kendi yaratılışları (varoluş) hakkında neden farklı görüşlere sahip olduklarını sorgulamak (MSB, 2013).

Öğrencilerde geliştirilmek istenen genel kazanımlar incelendiğinde, bilişsel alanda daha çok Alevilik inanç esaslarıyla, Alevi gelenek ve kültürüyle, dini tutum ve davranışlarla (ibadet) ilgili kazanımların geliştirilmek istendiği görülmüştür. Duyuşsal alanda öğrencilerden, Alevilik inanç esaslarını, gelenek ve kültürünü temsil edebilmesi, tutum ve davranışlarında bunlara yer verebilmesi beklenmektedir. Öğrencilerde geliştirilmek istenen devinişsel alan öğrenme kazanımlarına bakıldığında ise, bunların özellikle bilişsel ve duyuşsal alan öğrenme kazanımlarının gerçek hayata yansıtılmasıyla ilgili oldukları anlaşılmıştır.

\section{b. İslam Din Dersi Öğretim Programının Genel Kazanımları}

İslam Din Dersi Öğretim Programında kazanımlar, genel ve özel kazanımlar (ünite kazanımları) olmak üzere iki ayrı kategoride düzenlenmiştir. Genel kazanımlar, öğrencilerin ilköğretim kademesinin sonunda elde etmesi, bir diğer ifadeyle 4. sınıfın sonunda kendilerinde geliştirmeleri beklenen (genel anlamda) bilgi, beceri, tutum ve davranışları ifade etmektedir. Özel kazanımlar ise genel kazanımlardan hareketle ve daha ayrıntılı olarak belirlenen bilgi, beceri, tutum ve davranışları ifade etmektedir. İslam Din Dersi Öğretim Programında yer alan genel kazanımlar şunlardır:

a. Öğrencilerin dini fenomenleri anlaması ve bunları açıklaması. Bunu yaparken mevcut/ön bilgilerini kullanması ve ihtiyaç duyulan yeni bilgileri edinmesi.

b. Öğrencilerin bazı dini kavramlara ve ibadet çeşitlerine hâkim olması ve gerektiğinde bunları hayata geçirebilmesi.

c. Öğrencilerin oryantasyon bilgisine sahip olması, kendi yorumlarını, değerlendirme ve çözüm önerilerini geliştirmesi ve bunları açıklaması.

d. Öğrencilerin tutum geliștirme ve davranıș sergilemede mevcut bilgi ve becerilerinden istifade edebilmesi, elde ettiği deneyim ve tecrübeleri göz önünde bulundurabilmesi.

e. Öğrencilerin mevcut bilgi ve becerilerinden din içi ve dinler arası ilişkilerde istifade edebilmesi (MSB, 2014).

Öğrencilerde geliştirilmek istenen genel kazanımlar incelendiğinde, 
bunların özellikle mevcut/ön bilgi ve becerilerin, deneyim ve tecrübelerin yenileriyle ilişkilendirilmesi üzerine kurgulandığı görülmektedir. Bunda, öğretim programının Korelasyon Didaktiği Yaklaşımı temel alınarak geliştirilmiş olmasının önemli bir etkisi bulunmaktadır. Ayrıca öğrencilerden dini kavramlara, dini fenomenlere ve ibadet çeşitlerine hâkim olmaları; sahip oldukları inancı yaşamaları ve söz konusu ibadetlere katılmaları da istenmektedir.

\section{Alevilik İle İslam Din Dersi Öğretim Programlarının Ölçme ve Değerlendirme Boyutu}

a. Alevilik Din Dersi Öğretim Programının ölçme ve Değerlendirme Boyutu

Öğretim programında Performans Ölçme ve Değerlendirme Yaklaşımı benimsenmektedir. Performans Ölçme ve Değerlendirme, bir hedefe ulaşmak için önceden belirlenmiş ölçütlere göre bir faaliyetin sonuçlarının değerlendirilmesidir. Öğretim programında yer alan performans ölçütleri şunlardır:

a. Öğrencinin eğitim ve öğretim sürecinde edindiği bilgileri muhafaza etmesi, başka durumlara uyarlaması.

b. Öğrencinin derse ve ders konularına gösterdiği ilgi (sınıf içi etkinlik ve projelerde görev almak gibi).

c. Öğrencinin ders konu ve içeriği ile kendi deneyim ve tecrübelerini ilişkilendirme durumu.

d. Öğrencinin öğrendiği teknik kavramları derste kullanma durumu.

e. Öğrencinin hazırlamış olduğu portfolyo, afiş, poster, dosya vb. ürünler.

f. Öğrencinin işbirliğine açık ve istekli olma durumu (MSB, 2013).

Öğrencilerin başarı durumu, ölçme sonucunun performans ölçütleriyle karşılaştırılması sonucunda aldıkları notlarla belirlenmektedir. Öğrencilerin din hakkındaki düşünceleri, ayrıca dindar olup olmama durumu ölçme sürecinin bir parçası olmamakta, not ile değerlendirilmemektedir.

Öğrencilerin ölçme ve değerlendirme sonunda alabilecekleri notlar dört kategoride düzenlenmiştir. Bunlar:

a. Öğrencinin kendi algılarını veya geliștirdiği muhtevayı/ürünü uygun şekilde ortaya koyabilmesi, tanımlaması ve buna atıfta bulunabilmesi (Not olarak karşıll: Yeterli- Tatmin Edici arası).

b. Derste edindiklerini kendi hayatı ve ilgi alanlarıla 
ilişkilendirebilmesinin yanı sıra bunlara yenilerini ekleyebilmesi ve uygun şekilde genişletebilmesi (Not olarak karşılığı: Tatmin Edici).

c. Öğrencinin konu ile ilgili bilgileri uygun yöntem ve tekniklerle analiz etmesi, elde ettiği sonuçları diğer gerçekliklere uyarlayabilmesi (Not olarak karşılığı: İyi).

d. Derste öğrendikleriye hedef davranışlar arasında anlamlı ilişkiler kurabilmesi (Not olarak karşıllı̆ı: Pek İyi) (MSB, 2013).

Öğretmenler, öğrenci başarısını değerlendirmede söz konusu kategorileri temel alan 4'lü (Yeterli, Tatmin Edici, İyi, Pek İyi) puanlama anahtarı kullanmaktadır. Bu süreçte öğrencilerden sınıf içi ve sınıf dışı çalışmalarda aktif olmaları, yapılacak sınıf içi/dışı çalışmalara katkı sunmaları, işbirliğine açık ve özverili olmaları beklenmektedir.

\section{b. İslam Din Dersi Öğretim Programının Ölçme ve Değerlendirme Boyutu}

İslam Din Dersi Öğretim Programının ölçme ve değerlendirme boyutu incelendiğinde; burada öğrencilerin eğitim-öğretim süreci sonunda elde edecekleri bilgi ve becerilerin yanı sıra derste gösterecekleri çaba ve sağlayacakları ilerlemenin de bir "başarı" olarak değerlendirileceği ifade edilmektedir. Öğrencilerin takım çalışmalarına yatkın olma, grup çalışmalarına katılma ve bu çalışmalara katkı sunma durumu da ölçme ve değerlendirme işleminde dikkate alınacak diğer değişkenlerdir (MSB, 2014). Öğretim programının ölçme ve değerlendirme boyutunu oluşturan temel bileşenler şunlardır:

a. Öğrencinin derse sözlü katılımı (derste sözlü sunum, sorulara ve önerilere verilen cevaplar vb.).

b. Öğrencinin yazılı katılımı (çeşitli çalışmalardan elde edilen sonuçlar, yazılan metinler vb.).

c. Öğrencilerin dersle ilgili yaratıcı çalışmaları (çizilen resimler, oyunda canlandırılan kişilik veya roller, bestelenen şarkılar vb.).

d. Öğrencilerin farklı toplumsal süreçlerde sorumluluk bilinciyle inisiyatif alması ve katkı sunması (grup çalışmalarında sorumluluk alma ve görevleri yerine getirme, proje odaklı çalışma isteği).

İslam Din Dersinde öğrencilerden, kendilerinde duyuşsal alan öğrenme kazanımlarını (duygu, tutum, değer vb.) geliştirmeleri de beklenmektedir. Öğretim programında, öğrencilerin dine ve dini olana karşı olumlu bir tutum ve anlayış geliştirmelerine, bunun için uygun öğrenme 
ortam ve olanaklarının oluşturulmasına ayrı bir önem atfedilmektedir. Bununla beraber öğrencilerin din hakkındaki düşünceleri ve dini pratikleri, bir başka ifadeyle dini bilgiyi hayata geçirme, yaşama ve uygulama; dini ritüel ve ibadetlere katılma durumu ölçme ve değerlendirme sürecinin dışında bırakılmaktadır (MSB, 2014).

\section{Sonuç}

$\mathrm{Bu}$ çalışmada Almanya'nın Kuzey Ren-Vestfalya Eyaletinde uygulanmakta olan Alevilik ile İslam din dersi öğretim programları incelenmiş; benimsenen yaklaşım, amaç, yapı ve içerik ile ölçme ve değerlendirme boyutları karşılaştırılmıştır. Elde edilen verilerden hareketle ulaşılan sonuçlar şu şekildedir:

Alevilik ile İslam din dersi öğretim programlarının hangi din eğitimsel yaklaşım temel alınarak hazırlandı̆̆ açık ve net bir şekilde ifade edilmemiştir. Ancak öğretim programlarında yer alan açıklamalar incelendiğinde, her iki öğretim programının da mezhep merkezli -kısmen dinlerarası açlımlı- din öğretimi yaklaşımı temel alınarak geliştirildiği anlaşılmıştır.

Öğretim programlarının geliştirilmesinde birden fazla yaklaşımın esas alındığı görülmüştür. Programda Mezhep Merkezli Dinlerarası Açılımlı Din Öğretimi Yaklaşımının yanı sıra Korelasyon Didaktiği Yaklaşımına yer verildiği de görülmüștür. Bu yönüyle her iki öğretim programında da aynı din eğitimsel yaklaşımın temel alındığı söylenebilir. Her iki programın da öğrencilerin proje ve araștırma tabanlı faaliyetlerine, gösterdikleri performansa, işbirliğine ve aktif katılımına odaklandığı tespit edilmiştir. Öğrencilerin eğitim-öğretim sürecinde aktif olmaları, deneyim ve tecrübelerini paylaşmaları ve yaparak-yaşayarak öğrenmeleri için gerekli tüm önlemlerin alınmasına çalıșıldığı görülmüștür. Buna göre her iki öğretim programının da öğrenci merkezli ve yapılandırmacı bir anlayışla hazırlandığı ifade edilebilir. $\mathrm{Bu}$ anlamda her iki öğretim programının da aynı anlayışla geliştirildiği, aynı eğitim ve öğretim yaklaşımı temel alınarak hazırlandığı sonucuna ulaşılmıştır.

Öğretim programlarının temel hedefleri incelendiğinde; her iki öğretim programının da bireylerin dini kimlik gelişimine odaklandığı görülmüştür. Öğrencilerin kendi yaşamlarını, tutum ve davranışlarını düzenlemede dini kaynaklardan istifade etmeleri, dini bilgi ve geleneğin rehberliğinden yararlanmaları hedeflenmiștir.

Öğrencilerin farklı din ve dünya görüşüne sahip insan ve toplulukları tanımaları ve bunlarla karşılıklı saygı ve hoşgörü iklimi geliştirmeleri, barış 
ve diyalog içerisinde yaşamalarına katkı sunma hedefinin, her iki programda da yer aldığı görülmüştür. Öğretim programlarında bu anlamda bir farklılaşma söz konusu değildir.

Alevilik ile İslam din dersi öğretim programları yapısal özellikleri ve konu içerikleri açısından incelendiğinde her iki öğretim programının da öğrenme alanları üzerine yapılandırıldığı görülmüştür. Burada en temel fark ünitelerin düzenlenmesiyle ilgilidir. Üniteler, Alevilik Din Dersi Öğretim Programında sınıf düzeylerine göre gruplandırılırken, İslam Din Dersi Öğretim Programında öğrenme alanlarına göre düzenlenmektedir. Üniteler İslam Din Dersi Öğretim Programında ilkokul kademesinin tamamı (1-4. Sinıflar) için birlikte verilmektedir.

İslam Din Dersi Öğretim Programı altı öğrenme alanı ve bu öğrenme alanlarını oluşturan 18 ünite halinde düzenlenmektedir. Alevilik Din Dersi Öğretim Programı ise dört öğrenme alanı ve yine bu öğrenme alanlarını oluşturan 28 üniteden meydana gelmektedir. Öğretim programları arasında öğrenme alanları sayılarından dolayı ünitelendirme ve ünitelerin sınıf düzeylerine göre dağılımında ciddi farklılıklar bulunmaktadır. Alevilik Din Dersi Öğretim programı ünite sayılarından da anlaşılacağı üzere daha geniş bir konu içeriğine sahiptir. Buna göre, Alevilik Din Dersi Öğretim Programının İslam Din Dersi Öğretim Programından daha kapsamlı olduğu söylenebilir.

İslam Din Dersi öğrenme alanları ünitelerden, üniteler de özel kazanımlardan oluşmaktadır. Alevilik Din Dersi Öğretim Programında özel kazanımlara yer verilmemiştir. Öğrenme alanları ünitelerden ve bunların altında yer alan kısa açıklamalardan meydana gelmektedir. Öğretim programları arasında hem ünitelendirme hem de ünitelerin sınıf düzeylerine göre dağılımında ciddi farklılıklara ulaşılmıştır.

Alevilik ile İslam din dersi öğretim programlarında içerik, genel olarak inanç esasları, kültür ve gelenek temel alınarak oluşturulmuştur. Bununla beraber İslam Din Dersi Öğretim Programında yer alan pek çok konu (Temel İnanç Esasları, Vahiy-Tebliğ, İslam Toplumu/Ümmet vb.) Alevilik Din Dersi Öğretim Programında bulunmamaktadır. Benzer şekilde Alevilik kültür ve geleneğine dair pek çok konu İslam Din Dersi Öğretim Programında yer almamıştır. Alevilik programında Musahiplik, Cemevi, Oniki İmam vb. konular ayrıca yer ayrılmışken İslam Din Dersi Programında bu konulara yer verilmediği görülmüștür. Programda cami, kilise ve sinagog arasındaki ilişkiye, benzerliklere ve belirgin farklara değinilirken, cem evlerine ilişkin herhangi bir bilgiye yer verilmemiştir. Cem evlerinin belirgin-ayırt edici bir 
mimarisinin olmaması, ayrıca cem evlerinin cami-mescid dışı mekânlar kabul edilmemesi bunda etkili olmuş olabilir.

Alevilik ve İslam din dersi öğretim programları, farklı öğrenme alanlarından, farklı ünitelerden ve genellikle farklı konu içeriklerinden meydana gelmiştir. Alevilik ile İslam din dersi öğretim programlarında her ne kadar Allah, Hz. Muhammed, Ehl-i Beyt, ibadet mekânları, dini gün ve geceler, diğer dinler, kutsal kitaplar vb. ortak konulara yer veriliyor olsa da, genel olarak farklı konu içeriklerine (muhteva), farklı anlayış ve değerlendirmelere sahip oldukları görülmüștür. "Aleviler, Hz. Muhammed'in ilahi mesaja muhatap olduğuna inanmaktadır. Bununla beraber onlar, ilahi mesajın orijinalliğini, ilk günkü özelliğini kaybettiğini düşünmektedir” (MSB, 2013) ifadesi, söz konusu anlayış ve değerlendirme farkını ortaya koyması bakımından somut bir örnektir. Bu ve benzeri örnekler, her iki öğretim programını muhteva açısından birbirinden ayıran temel özellikler olarak değerlendirilebilir.

Alevilik Din Dersine konu edilen dini gün ve geceler (Nevruz Bayramı, Muharrem Ayı ve Orucu, Aşure Günü) İslam dinine atıfla ele alınırken, İslam Din Dersi Öğretim Programında yer alan dini gün ve geceler Alevilikle ilişkilendirilmemiştir.

Alevilik ve İslam din dersi öğretim programlarının her ikisinde de semavi dinlere ve dini fenomenlere (dini gün ve geceler, ibadet ve ritüeller vb.) yer verildiği, bunlar arasında karşılaştırmalar yapıldığg da tespit edilmiştir. Ayrıca diğer din mensuplarıyla birlikte yaşamayı, saygı ve sevgi iklimini geliştirmeyi mümkün kılacak konu içeriklerine yer verildiği de görülmüştür. Burada dikkat çekici olan, İslam dininin Alevilik Din Dersi Öğretim Programında diğer dinler arasında gösterilmiş olmasıdır.

İslam Din Dersi Öğretim Programında İslam dininin temel kaynaklarından, bir diğer ifadeyle Kur'an ve Sünnet'ten istifade edilirken, Alevilik Din Dersinde Alevi kültür ve geleneği etrafında şekillenen kaynaklara (Buyruk, Nehcü'l Belâğa, Velayetname, Makalat vb.) atıfta bulunulmaktadır.

Alevilik Din Dersi Öğretim Programının genel kazanımları bilişsel, duyuşsal ve devinişsel olmak üzere üç ayrı başlık altında maddeleştirilirken, İslam Din Dersi Öğretim Programında genel kazanımlar, bilişsel, duyuşsal ve devinişsel alan ayrımı yapılmaksızın tek bir başlık altında (Genel Kazanımlar) düzenlenmiştir. Alevilik Din Dersi Öğretim Programında öğrencilere bilişsel alanda, özellikle Alevilik inanç ve geleneğiyle ilgili temel bilgilerin kazandırılmasının hedeflendiği görülmüştür. Devinişsel alan 
öğrenme kazanımlarına bakıldığında, bunların daha çok bilişsel alan öğrenme kazanımlarının tutum ve davranışlara yansıtılması, gerçek hayatta uygulanmasıyla (Aleviliği yaşamak, temsil etmek, diğer inanç sistemleriyle karşılaştırmak, kurallara uymak vb.) ilgili olduğu tespit edilmiştir. Son olarak duyuşsal alan öğrenme kazanımlarıyla bu derse katılan öğrencilerin Aleviliği sevmesinin, Alevilik inanç esaslarına değer vermesinin ve Aleviliğe karşı olumlu bir tavır geliştirmesinin hedeflendiği sonucuna ulaşılmıştır. Programda öğrencilerden Alevi gelenek ve değerlerini kendi yaşamlarıyla ilişkilendirmeleri; bunları diğer insanlarla kuracakları ilişkileride ve bir arada yaşama kültürü geliştirmede bir temel ölçüt olarak işe koşmaları istenmiştir.

İslam Din Dersi Öğretim Programında öğrencilerden, Alevilik Din Dersi Öğretim Programında olduğu gibi temel inanç esaslarını bilmeleri, dini form ve fenomenleri kavramaları ve bunları hayata uyarlamaları istenmiştir. Mevcut bilgi ve becerilerinden toplumsal ilişkilerini düzenlemede istifade etmeleri ve bir arada yaşama kültürü geliştirmede işe koşmaları hedeflenmiştir. Bu yönüyle her iki öğretim programının da benzer kazanım ifadelerine sahip oldukları söylenebilir. Ancak bu durum, öğretim programlarının muhteva ve anlayış bakımından da aynı oldukları anlamına gelmemektedir. Alevilik ile İslam din dersi öğretim programlarını genel kazanımları açısından karşılaştırdığımıza, her iki öğretim programının da öğrencilerin temel inanç esaslarını bilmelerine, ibadet şekillerini ve dini fenomenleri kavramalarına ve bunları gerçek hayatta tatbik etmelerine odaklandığı sonucuna ulaşılmıștır.

Araştırma sonucunda her iki öğretim programının da benzer ölçme ve değerlendirme yaklaşımlarına sahip oldukları görülmüștür. Her iki öğretim programı da öğrencilerin bilgi, beceri ve tutumlarını ölçme ve değerlendirmede alternatif ölçme ve değerlendirme yöntemlerine odaklanmaktadır. Ölçme ve değerlendirme anlayışının çeşitli ölçme araçlarıyla desteklendiği, süreç odaklı değerlendirme yöntemlerinin yanı sıra performans odaklı değerlendirme yöntemlerine de yer verildiği tespit edilmiştir. Dönem sonu sınavlarının (sözlü-yazılı) yanı sıra öğrencilerin süreç içerisindeki başarı ve yeteneklerinin, ilgi ve aktif katılım düzeylerinin, ürün dosyalarının (portfolyo), proje odaklı yaratıcı çalışmalarının (poster, afiş, resim, beste vb.) ve performans görevlerinin (rol oynama, canlandırma vb.) değerlendirildiği sonucuna da ulaşılmıştır. Her iki öğretim programında da öğrencilerin din hakkındaki duygu ve düşüncelerinin; dini ritüel ve |402| seramonilere (ibadet, ayin vb.) katılma durumlarının ölçme ve değerlendirme süreç ve işleminin dışında bırakılacağı ifade edilmektedir. 
Alevilik ile İslam din dersi öğretim programları her ne kadar bazı noktalarda birbirinden ayrılsa da yapısal anlamda bir benzerlikten (temel alınan yaklaşım, ölçme ve değerlendirme boyutu vb.) söz edilebilir. Ancak içerik ve içeriğin anlaşılma ve yansıtılma biçimine bakıldığında aralarında belirgin farkların bulunduğu da görülmektedir. Bu durum (İslam dini ile) aynı peygambere, aynı kitaba ve aynı kutsala yönelen Aleviliği; amel ve itikada dair farklı yorum ve anlayışlar barındırmasının ötesinde, İslam'dan ayrı bir din gibi gösterme çabası olarak da değerlendirilebilir. Oysa her iki program ve öğretide öne çıkan değerler ve kullanılan bilgi, kültürel unsur ve geleneksel yorumlar, Aleviliğin İslam dışı bir anlayış olduğu sonucuna ulaşmamızı engellemektedir. Günümüzde Alevilik; İslam kültür geleneği içinde aşırı-1lımlı-orta yolcu birçok yorum ve anlayış gibi tarihsel ve güncel bakış açıları ile kendi özgün yerini korumaya devam etmektedir.

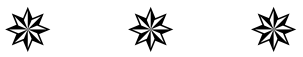

\section{KAYNAKÇA}

ASBRAND, B. (1999). Zusammen Leben Und Lernen Im Religionsunterricht. Frankfurt: Iko-Verlag.

BAMF. (2009). Muslimisches Leben In Deutschland. Nürnberg: Bundesamt Für Migration Und Flüchtlinge.

DEMIREL, Ö. (2000). Kuramdan Uygulamaya Eğitimde Program Geliștirme. Ankara: Pegem Yayıncılık.

Deutscher Bundestag. (2007). Grundgesetz Für Die Bundesrepublik Deutschland. Baden-Baden: Koelblin-Fortuna-Druck.

HECKEL, M. (2005). Religionsunterricht Auf Dem Prüfstand: Konfessionell Unkonfessionell - Interreligiös - Interkonfessionell - Konfessionell Kooperativ? Der Rechtliche Rahmen Des Religionsunterrichts Im Säkularen Verfassungsstaat. Zeitschrift Für Theologie Und Kirche, 102(2), 246-292.

KIEFER, M. (2009). Islamwissenschaftliche Thesen Zum Islamischen Religionsunterricht. M. Kiefer (Ed.), Islamunterricht-Islamischer Religionsunterricht-Islamkunde İçinde (S. 205-212). Bielefeld: Transcript Verlag.

KIEFER, M. (2011). Art Und Umfang Der Bestehenden Angebote, Unterschiede, Perspektiven. Islamischer Religionsunterricht In Deutschland Perspektiven Und Herausforderungen İçinde (S. 60-71). Nürnberg: Bundesamt Für Migration. 
LANDTAG Nrw. (2011). Gesetz Zur Einführung Von İslamischem Religionsunterricht Als Ordentliches Lehrfach (7. Schulrechtsänderungsgesetz). Https://Recht.Nrw.De. Adresinden Edinilmiştir.

MSB. (2013). Lehrplan Für Die Grundschule In Nordrhein-Westfalen Alevitischer Religionsunterricht. Frechen: Ritterbach Verlag.

MSB. (2014). Lehrplan Für Die Grundschule In Nordrhein-Westfalen Islamischer Religionsunterricht. Erftstadt: Ritterbach Verlag.

STATISTA. (2019). Anzahl Der Muslime İn Deutschland Nach Glaubensrichtung. Erișim: Https://De.Statista.Com/Statistik/Daten/Studie/ 76744/Umfrage/Anzahl-Der-Muslime-İn-Deutschland-NachGlaubensrichtung/

TOPÇUK, A. (2015). Almanya'da Uygulanan İslam Din Dersi Hakkında Bir Değerlendirme (Kuzey Ren Westfalya Örneği). Çukurova Üniversitesi İlahiyat Fakültesi Dergisi, 15 (1), 249-269.

TOSUN, C. (2009). Almanya'da Alevi Din Derslerinin Tarihsel Gelişimi Ve Türkiye'ye Muhtemel Yansımaları. Dini Araștırmalar Dergisi, 12 (33), 99-106.

TOSUN, C. \& ZENGIN, H. K. (2009). Almanya'daki Alevilik Din Dersi Programları (1.-4. Sınıflar) Üzerine Bir İçerik Analizi. Dini Araştırmalar Dergisi, 12 (33), 345-380.

TOSUN, C. (2015). Din Eğitimi Bilimine Giriș. Ankara: Pegem Akademi Yayıncillk.

YILDIRIM, A., \& ŞİMŞEK, H. (2016). Sosyal Bilimlerde Nitel Araştırma Yöntemleri. Ankara: Seçkin Yayıncılık.

ZENGiN, H. K. (2008). Almanya'da İslam Din Öğretimi Modelleri. Ankara Üniversitesi İlahiyat Fakültesi Dergisi, 49 (2), 245-268.

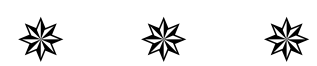




\title{
THE COMPARISON OF ALEVI RELIGION CURRICULUM AND ISLAM RELIGION CURRICULUM IN GERMANY (NRV)
}

\author{
D Hasan SÖZENa
}

\section{Extended Abstract}

This study is carried out to compare and to reveal the similarities and differences between Religious Education Curriculum for Alevies (Grades 14) and the Islamic Religious Education Curriculum (Grades 1-4), which are being implemented in the North Rhine-Westphalia State of Germany. Accordingly, the basic approach, purpose, content, measurement and evaluation situations on which both programs are based are examined and evaluated based on the data obtained. The main problem of the study is "The comparison of Alevi and Islamic religion course teaching programs implemented in the German state of North Rhine-Westphalia".

In the study, qualitative research methods and document analysis are used, and the teaching programs in question are examined in terms of the approach over curriculum, the structure and content of the teaching programs, objectives and overall attainment, as well as evaluational dimensions of the course. The data obtained as a result of the analysis are grouped according to the criteria of similarity and difference, and the differences between the curriculums are interpreted based on the results obtained. During the analysis process, both teaching programs are examined closely and the necessary encodings are made. No categories have been previously defined for coding, except for problems and sub-problems.

The documents examined in the study are the Alevi religion course curriculum published in 2013 by the Ministry of Education of the German state of North Rhine-Westphalia, (1-4 Classes) and an Islamic religion course curriculum published by the same ministry in 2014 (1-4. Classes). The main

a Prof., Bayburt University, hasan.sozen@mail.com 
reason for the preference of North Rhine-Westphalia state teaching programs in the study is that the province in question has the most crowded Muslim student population in Germany.

The study is the first in terms of comparing the basic approach, goals, course subjects, measurement and evaluation dimensions on which both curriculum are based, and revealing similarities and differences between them. It is believed that the research will make a significant contribution to program development in religious education and training in this aspect and offer a different perspective.

As a result of the study, it is determined that the Alevi and Islamic religious education curriculum are similar with the approaches, objectives, structural features and measurement and evaluational dimensions. Both teaching programs are based on the approach of faith-centered/confessional, interfaith-oriented religious teaching and the approach of correlation didactics. Alevi and Islamic religious education course curricula focus on project and research-based activities of students, their performance, cooperation and active participation. It has been observed that all necessary precautions have been taken for students to be active in the educational process, to share their experience, and to learn by doing and experiencing. It is accordingly, concluded that both curriculum have been prepared with a student-centred and constructivist understanding.

When the main objectives of the curriculum are examined, it is seen that they focus on the development of religious identity of individuals and have similar measurement and evaluation approaches. It has been observed that students use religious references in regulating their own lives, attitudes and behaviours, and use the guidance of religious knowledge and tradition.

There are both significant differences in sections of the curriculums and the patterns of the units according to class levels among the curriculum. It is determined that religious education curriculum for Alevies curriculum has a wider and more detailed subject content than the Islamic religious Education Curriculum. Content in both curriculum is based on the principles of faith, culture and tradition in general. However, many topics in the Islamic religion course curriculum (basic principles of faith, revelation-communique, Islamic Society/Ummah, etc.) is not included in the curriculum of Alevi Religion course. Similarly, many topics related to Alevi culture and tradition are not located in the Islamic religion course curriculum. In addition, these topics such as Musahiplik, Cemevi, Twelve Imams, are observed that have not included in the Islamic religion course program, while the topics are reserved 
in Alevi teaching program. In the Islamic Religious program, the relationship between the mosque, the church and the synagogue, similarities and obvious differences are addressed, while no information about the Cemevi is given.

In both teaching programs, although common subjects such as Allah, $\mathrm{Hz}$. Muhammad, Ehl-i Beyt ( family of Hz. Muhammad), places of worship, religious days and nights, other religions, holy books, etc. are concluded, they have subjects, contents, understandings and approaches distinctly. The religious days and nights (The Feast of Nowruz, the month of Muharram and the Ashura fast, the day of Ashura) mentioned in the Alevi religion course are considered with reference to the Islamic religion, while the religious days and nights included in the Islamic religion course curriculum are not associated with Alevism.

In the Islamic religion course curriculum, the main sources of the Islamic religion are used, in other words, the Koran and Sunnah are utilized, on the other hand, in the course of Alavi religion, the main sources formed around Alevi culture and tradition (Buyruk, Nehcü'l Belaga, Velayetname, Makalat, etc.) are investigated.

In the Islamic religion course curriculum, students are expected to know the basic principles of faith, understand religious forms and phenomena, and adapt them to life, as in the Alevi religion course curriculum. It is aimed that they benefit from their existing knowledge and skills in regulating their social relations and run to work in developing a culture of coexistence. In this aspect, it can be said that both curriculum have similar objectives. But this does not mean that the curriculum is the same in terms of content and understanding. Although Alevi and Islamic religion course curriculum are different from each other at some points, it can be mentioned there is a structural similarity (based approach, measurement and evaluation dimension, etc.) But focusing the way content and content which are understood and reflected, it is also seen that there are significant differences between them. This situation (with the religion of Islam) means for Alevi which tends towards the same prophet, the same book and the same sacred; yet beyond having different interpretations and understandings about deeds and creed, can also be regarded as an effort to present Islam as a different religion. However, the values that stand out in both programs and teachings, as well as the knowledge, cultural elements and traditional interpretations used, prevent us from concluding that Alevism is a non-Islamic understanding. Currently, Alevism continues to maintain its original place in the Islamic cultural tradition with historical and current perspectives, such 
Hasan SÖZEN

as extreme-moderate-radical interpretations and understanding.

Keywords: Religious Education, Curriculum, Islam, Alevism, Germany.

深溫

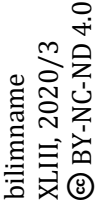

|408| 